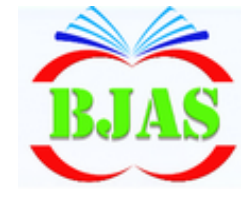

ISSN $1814-5868$
Available online at http://bjas.bajas.edu.iq

https://doi.org/10.37077/25200860.2022.35.1.03

College of Agriculture, University of Basrah

Basrah J. Agric. Sci. 35(1), 35-49, 2022

\section{Basrah Journal \\ of Agricultural \\ Sciences}

E-ISSN: 2520-0860

\title{
Identification and Characterization of Xanthan Gum Produced from Date Juice by a Local Isolate of Bacteria Xanthomonas campestris
}

\author{
Fatima W. Al-Roomi \& Shayma T. G. Al-Sahlany* \\ Department of Food Science, College of Agriculture, University of Basrah, Iraq \\ *Corresponding author email: shayma.gddoa@uobasrah.edu.iq \\ Received 27 June 2021; Accepted 13 September 2021; Available online 23 February 2022
}

\begin{abstract}
Xanthan gum is a microbial polysaccharide produced by the bacteria Xanthomonas spp. Seven local isolates of Xanthomonas campestris were used after microscopic and biochemical tests identified them. The isolates were subjected to a screening for xanthan production in medium broth consisting of 20 g.L-1 sucrose, 0.1 g.L-1 urea, and 1 g.L-1 K2HPO4. Isolate X1 showed the highest yield, which reached 6.26 g.1-1. The isolate was confirmed by a $16 \mathrm{~S}$ rRNA test, and it was recorded in the gene bank with the code MZ262533. Xanthan gum was produced from date juice at a concentration of 3.5 $\mathrm{ml}$ (1.5 g glucose.100 ml-1 from the production medium, with the highest yield being 18.9 g.l-1. The resulting xanthan gum was identified by using FTIR, TLC and HPLC techniques, and it was the same chemical as xanthan gum. In the manufacture of xanthan gum and its usage in food, alternative media made from agricultural waste can be employed.
\end{abstract}

Keywords: Date juice, Xanthomonas campestris, Xanthan gum.

\section{Introduction}

Xanthan gum is one of the secondary metabolites produced and secreted outside the living cell. It is a heterogeneous microbial polysaccharide that is mainly produced from the fermentation of carbohydrates by isolates of the species belonging to the genus Xanthomonas (Palaniraj, \& Jayaraman, 2011). Among the most important species producing this gum is $X$. campestris; xanthan gum has a high molecular weight, similar in structure to cellulose. It consists of two glucose molecules linked by a $(\beta, 1-4)$ glycosidic bond that stabilizes compound. Sub-chains of xanthan gum contain two molecules of mannose and one molecule of glucuronic acid alternately (Sworn, 2021).
Xanthan gum contains residues of pyruvic acid and acetyl. The amount of pyruvic acid that integrates with the gum and is a part of it varies according to the type of bacteria producing it. Usually, it ranges between 1$7.4 \%$ of the weight of the gum. The percentage of acetyl in the gum produced by $X$. campestris bacteria has reached $4.7 \%$ (Abbaszadeh et al., 2015).

Xanthomonas belongs to the family Xanthomonadaceae, which includes many species and genera. $X$. campestris is the typical type of this bacteria and is characterized by aerobic, Gram-negative growing at $25-35^{\circ} \mathrm{C}$. It is motile due to polar flagella and can produce 


\section{Al-Roomi \& Al-Sahlany / Basrah J. Agric. Sci., 35(1): 35-49, 2022}

many enzymes such as gelatinase and catalase. It forms a sticky mucous substance when it grows in a medium containing glucose (Kyrova et al., 2020).

Xanthan gum is produced by several bacterial species of the genus Xanthomonas under optimum conditions of temperature and $\mathrm{pH}$ and in the presence of a carbon source. Bacteria ferment many sugars, except lactose, to produce xanthan gum; three bacterial isolates were identified by using biochemical tests and a $16 \mathrm{~S}$ rDNA test; two isolates belong to $X$. campestris bacteria and the third isolate belongs to $X$. vesicatoria bacteria; they were used to produce xanthan gum, which amounted to 7 and $35 \mathrm{mg} .100 \mathrm{ml}^{-1}$ of medium respectively (Rojas et al., 2019).

Xanthan gum is characterized by its stability and high solubility in basic and acidic solutions, so it has become one of the best polymers used in food and other industries due to its stability when there are concentrations of salts; the properties of xanthan gum are affected by its molecular weight and the amount of its acetate and pyruvic acid content; the amount of acetate and pyruvic acid varies depending on the species of the genus Xanthomonas used in the production of the gum and the production conditions (Espert et al., 2019).

In addition to being non-toxic and biodegradable, xanthan gum has been widely used in cosmetics and medicines, and in many food industries as a thickener, stabilizer, emulsifier, and gelling agent (Nejadmansouri et al., 2020). Xanthan gum is produced by fermenting glucose and sucrose as a carbon source, then separated and purified. Many agricultural and industrial wastes, such as molasses, whey, and date juice, are used to cut costs in the manufacturing process of xanthan gum (da Silva et al., 2017). Iraqi dates such as the Zahdi type are characterized by containing a high percentage of sugar, reaching more than $86.8 \%$, with glucose accounting for $32.77 \%$, fructose at $39.15 \%$, and $12.70 \%$ invert sugar (sucrose) (Al-Gboori \& Krepl, 2010). Due to the low cost of Iraqi dates, they can be used as a good carbon source in xanthan gum production. The current study aims to use local isolates capable of producing xanthan gum from a culture medium containing date juice as a carbon source.

\section{Materials \& Methods}

\section{Isolation sources}

Xanthomonas spp. were isolated from the leaves of infected plants, including Phoenix dactylifera, Bougainvillea, Uncaria tomentosa, Sansevieria trifasciata, Plumeria alba, Frangula alnus and Lawsonia inermis. After cleaning, the leaves were enriched by immersing $1 \mathrm{~g}$ of these leaves in $9 \mathrm{ml}$ Nutrient broth (Hi-media, India) for 24 hours at $30^{\circ} \mathrm{C}$. The enriched leaves were streaked on Phyto Buffered Starch Agar Base (Hi-media, India) as selective media for these bacteria. Bacterial cultures were incubated at $28^{\circ} \mathrm{C}$ for 4 days (Yuen et al., 1987).

\section{Identification of bacterial isolates}

The bacterial isolates obtained from the selective medium were identified according to what was mentioned in Bergey's Manual for the years 1974, 1994 and 2005. The phenotypic, microscopic and biochemical examinations (Saddler \& Bradbury, 2005).

\section{Screening and 16S rRNA test of isolate}




\section{Al-Roomi \& Al-Sahlany / Basrah J. Agric. Sci., 35(1): 35-49, 2022}

Screened isolates belonging to $X$. campestris on the basis of their production of xanthan gum in broth media. The 16S rRNA test used to confirm the identification of the most productive isolate. The $16 \mathrm{~S}$ rRNA test was conducted for the bacterial isolate using universal primers, $\mathrm{F}^{5}{ }^{5}$ AGTTTGATCCTGGCTCAG-31 R-5'GTTACCTTGTTTACGACTT ${ }^{-3}$, the amplification program included an initial denaturation at $94{ }^{\circ} \mathrm{C}$ for $3 \mathrm{~min}$, followed by 35 cycles of denaturation at $94^{\circ} \mathrm{C}$ for $45 \mathrm{sec}$, annealing at $56{ }^{\circ} \mathrm{C}$ for $45 \mathrm{sec}$, extension at $72{ }^{\circ} \mathrm{C}$ for $1 \mathrm{~min}$ and followed by a final extension at $72^{\circ} \mathrm{C}$ for $7 \mathrm{~min}$. After detect the PCR product by the electrophoresis method, the preparation, purification and sequencing of the PCR product was achieved at the BIONEER Company, Korea. PCR products were then exposed to treatment and re-correction before they were tested in the "BLAST program" supplied by the National Center for Biotechnology Information Service. http://www.ncbi.nlm.nih.govwhich (Loy et al., 2002).

\section{Cultural condition, inoculation and incubation}

The medium consisted of $20 \mathrm{~g}$ sucrose, $0.1 \mathrm{~g}$ urea, $1 \mathrm{~g} \mathrm{~K}_{2} \mathrm{HPO}_{4}$ and was used and dissolved in a litre of distilled water and the $\mathrm{pH}$ was adjusted to 7 (de Sousa Costa et al., 2014). The medium was distributed into $250 \mathrm{ml}$ Erlenmeyer flask at $100 \mathrm{ml}$ per flask and sterilized at $121^{\circ} \mathrm{C}$ for 15 minutes. After cooling, the flasks were seeded with a $5 \%$ $\left(35 \times 10^{9}\right.$ CFU.ml $\left.{ }^{-1}\right)$ inoculum of local isolate and incubated in a shaker incubator at $175 \mathrm{rpm}$ and $30^{\circ} \mathrm{C}$. The carbon source (sucrose) of the production medium was replaced with the prepared date juice according to what was mentioned in Khassaf et al. (2019). The following concentrations $(2.5,3.5,4.5,5.5$ and 6.5) percent of date juice, of the date juice, which are equivalent to $1.1,1.5,2.0,2.4$ and $2.8 \mathrm{~g}$ of sugar, estimated as glucose (Dubois et al., 1956).

\section{Isolation and purification of xanthan gum}

Following the end incubation time, centrifugation was carried out at $5500 \mathrm{rpm}$ for 40 minutes. The biomass was removed and the supernatant was collected Then, isopropanol was added at a ratio of $2: 1(\mathrm{~V}: \mathrm{V})$ to precipitate the xanthan gum, then incubated at refrigerator temperature for 12 hours, then centrifuged at a speed of $7000 \mathrm{rpm}$ for 30 minutes The above step was repeated again for xanthan purification and the precipitate was collected and dried at $50^{\circ} \mathrm{C}$ until a constant weight was achieved (Prabhakar et al., 2004; Rottava et al., 2009).

\section{Biomass estimation}

The precipitate was washed with distilled water twice, the biomass was weighed after being dried in an oven at $60^{\circ} \mathrm{C}$ until the weight was fixed.

\section{Xanthan gum identification}

\section{Infrared spectrum (FT-IR)}

The described method of Soleymanpour et al. (2018), as followed for FTIR spectra for the reference (Xanthan chemical (XG), Sigma company), Xanthan produced from standard media (XGP1) and xanthan produced from date juice media (XGP2) were recorded after mixing $1 \mathrm{mg}$ of the sample with $100 \mathrm{~g}$ of potassium bromide. The spectrum of effective groups of xanthan gum was observed between a 
Al-Roomi \& Al-Sahlany / Basrah J. Agric. Sci., 35(1): 35-49, 2022

wavelength of 4000 and $400 \mathrm{~cm}^{-1}$ at room temperature.

\section{Thin-layer chromatography (TLC)}

Xanthan gum solutions (XG, XGP1 and XGP2) were prepared by dissolving $0.02 \mathrm{~g}$ in $2 \mathrm{ml}$ of distilled water and injecting the samples into a thin layer which was put into a glass container containing a mixture of solvents (distilled water, butanol and ethanol) (4:5:5). After the solvent mixture reached the finish line, the plate was sprayed with a reagent consisting of $5 \%$ sulfuric acid, diluted with ethanol alcohol, and moved to an oven at $120^{\circ} \mathrm{C}$. Until the yellow colour of the separated spots appears, then the $\mathrm{R} f$ value was calculated by following equation (Mudoi et al., 2013).

\section{$\mathrm{R} f$ value $=\mathrm{X} / \mathrm{Y}$}

Where, $\mathrm{X}=$ compound's distance travelled, $\mathrm{Y}=$ the distance that solvent front has travelled

\section{High-performance liquid chromatography (HPLC)}

Gum solutions (XG, XGP1 and XGP2) were prepared by dissolving $5 \mathrm{mg}$ of each sample in $350 \mu \mathrm{L}$ of distilled water, $500 \mu \mathrm{L}$ acetonitrile and $20 \mu \mathrm{L}$ DMSO. The C18 column is used for separation. The mobile phase consisted of 75:25 (V: V) of distilled water and acetonitrile, respectively, and $100 \mu \mathrm{L}$ of formic acid at 60 ${ }^{\circ} \mathrm{C}$ using the HPLC device at the College of Pharmacy, University of Basrah. (Mudoi et al., 2013).

\section{Statistical analysis}

The significant differences between the mean of xanthan production treatments were calculated using the Completely Randomized Designs (CRD) and the analysis table ANOVA and the least significant difference test (LSD), probability level 0.05 by using the Genstat program version 12.1 (Ocimati, et al., 2018).

\section{Results \& Discussions}

\section{Morphological and microscopic tests of isolates}

The phenotypic and microscopic examination revealed that the colonies were creamy white, circular, sticky, rods, Gram-negative, and motile and these results were agreed with Saddler \& Bradbury (2005) and Tilahun et al. (2020) when they identified $X$. campestris bacteria as Gram-negative, motile and rod.

\section{Biochemical tests of isolates}

Table (1) shows the results of the biochemical tests of the seven isolates. All isolates showed the ability to produce catalase, gelatinase, casein hydrolysis, citrate utilization, gas production from glucose, $\mathrm{H}_{2} \mathrm{~S}$ gas production, esculin hydrolysis, resistance to the antibiotic erythromycin, grown at different temperatures and with different salt concentrations, fermentation of many sugars, as well as the production of a viscous substance in a medium containing $5 \%$ of glucose. These results agreed with Ndongo et al. (2018), which indicated the most important biochemical tests that confirm the belonging of bacterial isolates to the genus Xanthomonas. The seven isolates were given a negative result for the following tests: oxidase production, nitrate reduction, urea hydrolyze, lactose fermentation, and growth at $40^{\circ} \mathrm{C}$, confirming belonging to the Xanthomonas campestris isolates. These results agreed with the biochemical tests mentioned by Popovic et al. (2013) when identifying Xanthomonas bacteria locally isolated from cabbage, green cauliflower and turnip plants. 
Al-Roomi \& Al-Sahlany / Basrah J. Agric. Sci., 35(1): 35-49, 2022

Table (1): Biochemical characters of the isolates.

\begin{tabular}{|c|c|c|c|c|c|c|c|c|}
\hline & source of isolates & $\begin{array}{c}\text { Sansevieria } \\
\text { trifasciata }\end{array}$ & $\begin{array}{c}\text { Phoenix } \\
\text { dactylifera }\end{array}$ & Bougainvillea & $\begin{array}{c}\text { Uncaria } \\
\text { tomentosa }\end{array}$ & $\begin{array}{c}\text { Plumeria } \\
\text { alba }\end{array}$ & $\begin{array}{l}\text { Frangula } \\
\text { alnus }\end{array}$ & $\begin{array}{c}\text { Lawsonia } \\
\text { inermis }\end{array}$ \\
\hline & Isolate's symbol & X1 & X11 & $\mathrm{X12}$ & $\mathrm{X} 13$ & X15 & X24 & $\mathrm{X} 25$ \\
\hline \multirow{12}{*}{ 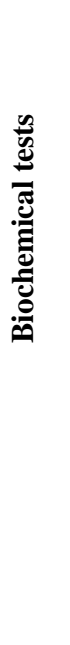 } & Citrate utilization & + & + & + & + & + & + & + \\
\hline & Hydrolysis of gelatin & + & + & + & + & + & + & + \\
\hline & Catalase production & + & + & + & + & + & + & + \\
\hline & $\mathrm{H}_{2}$ s production & + & + & + & + & + & + & + \\
\hline & Esculin hydrolysis & + & + & + & + & + & + & + \\
\hline & Oxidase production & - & - & - & - & - & - & - \\
\hline & Nitrate reduction & - & - & - & - & - & - & - \\
\hline & Urea hydrolysis & - & - & - & - & - & - & - \\
\hline & $\begin{array}{l}\text { Growth on nutrient } \\
\text { agar with } 5 \% \text { glucose }\end{array}$ & + & + & + & + & + & + & + \\
\hline & $\begin{array}{l}\text { Erythromycin } \\
\text { sensitivity test }\end{array}$ & $\mathrm{R}$ & $\mathrm{R}$ & $\mathrm{R}$ & $\mathrm{R}$ & $\mathrm{R}$ & $\mathrm{R}$ & $\mathbf{R}$ \\
\hline & casein hydrolysis & + & + & + & + & + & + & + \\
\hline & Gas from glucose & + & + & + & + & + & + & + \\
\hline \multirow{5}{*}{ 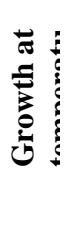 } & $25^{\circ} \mathrm{C}$ & + & + & + & + & + & + & + \\
\hline & $30^{\circ} \mathrm{C}$ & + & + & + & + & + & + & + \\
\hline & $35^{\circ} \mathrm{C}$ & + & + & + & + & + & + & + \\
\hline & $40^{\circ} \mathrm{C}$ & - & - & - & - & - & - & - \\
\hline & $0.5 \%$ & + & + & + & + & + & + & + \\
\hline \multirow{8}{*}{ 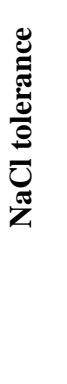 } & $1 \%$ & + & + & + & + & + & + & + \\
\hline & $2 \%$ & + & + & + & + & + & + & + \\
\hline & $3 \%$ & + & + & + & + & + & + & + \\
\hline & $4 \%$ & + & + & + & + & + & + & + \\
\hline & $5 \%$ & + & + & + & + & + & + & + \\
\hline & $6 \%$ & - & - & - & - & - & - & - \\
\hline & Fructose & + & + & + & + & + & + & + \\
\hline & Galactose & + & + & + & + & + & + & + \\
\hline \multirow{9}{*}{ 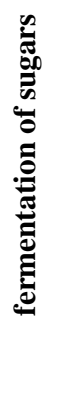 } & Melibiose & + & + & + & + & + & + & + \\
\hline & Sucrose & + & + & + & + & + & + & + \\
\hline & Glucose & + & + & + & + & + & + & + \\
\hline & Mannose & + & + & + & + & + & + & + \\
\hline & Lactose & - & - & - & - & - & - & - \\
\hline & Cellobiose & + & + & + & + & + & + & + \\
\hline & Maltose & + & + & + & + & + & + & + \\
\hline & Arabinose & + & + & + & + & + & + & + \\
\hline & Xylose & + & + & + & + & + & + & + \\
\hline
\end{tabular}

+: positive test, -: negative test, $R$ : resistance

\section{Screening bacterial isolates}

Fig. (1) shows the amount of xanthan gum produced from the identified bacterial isolates. The highest yield was obtained in case of the isolate $\mathrm{X} 1$ isolated from the leaves of
Sansevieria trifasciata, which amounted to 6.26 g. $1^{-1}$, while the lowest yield was for X15 isolate which was 5 g. $1^{-1}$ 


\section{Al-Roomi \& Al-Sahlany / Basrah J. Agric. Sci., 35(1): 35-49, 2022}

These results are consistent with Kalogiannis et al. (2003) who obtained different production rates of xanthan gum when using four strains belonging to $X$. campestris isolated locally from lemon trees. This showed the effect of the bacterial strain on the amount of gum produced. While Makut et al. (2018), studied the effect of different locally isolated strains from plant leaves (mango, orange, rice, melon and sugar cane) belonging to $X$. campestris on the production of xanthan gum, and the highest yield of gum obtained by the bacterium isolated from orange leaves was $1.25 \mathrm{~g} \cdot \mathrm{l}^{-1}$.

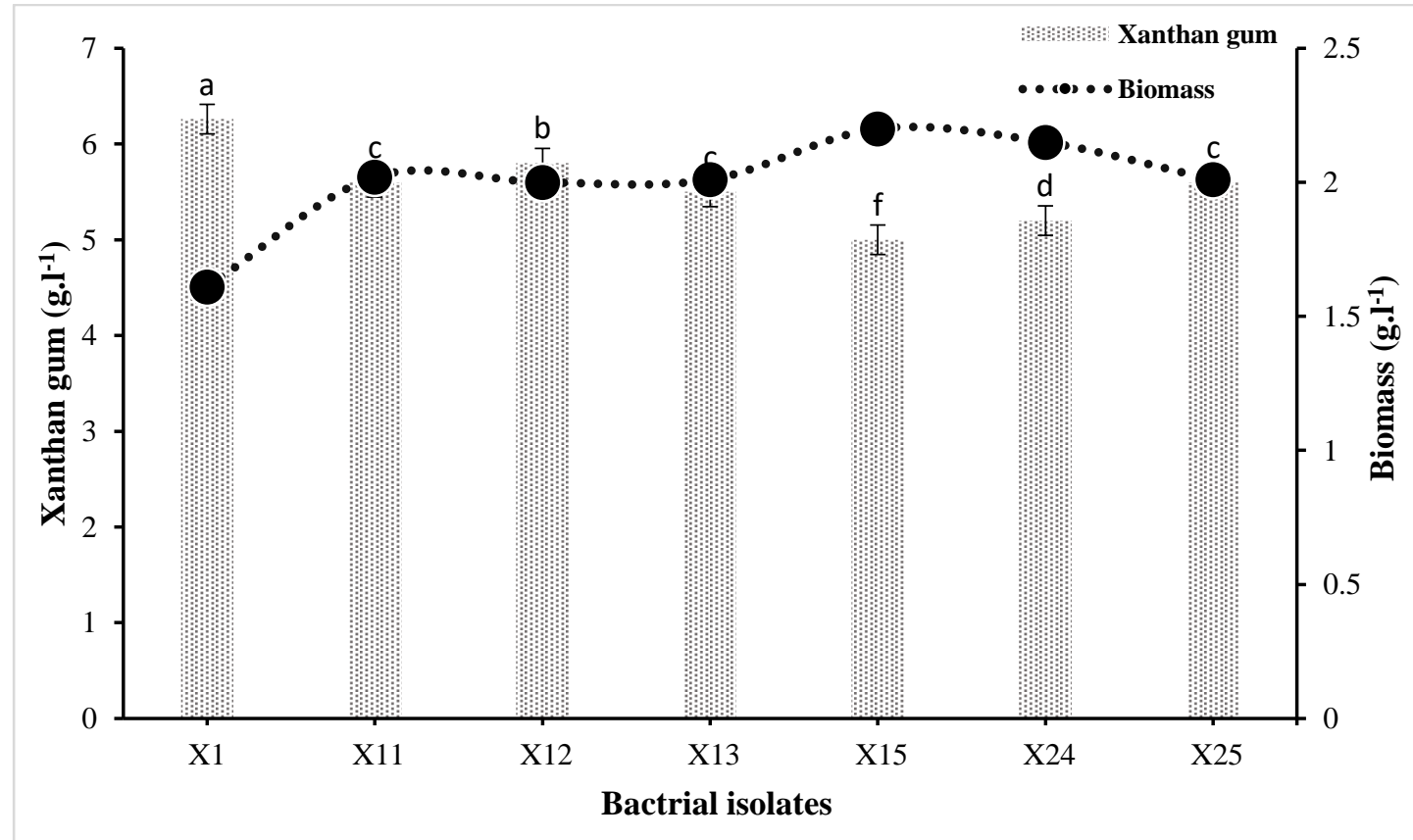

Fig. (1): Biomass dry weight and produced xanthan by $X$. campestris isolates 16S rRNA test for the most productive bacterial isolate.

The 16S rRNA test was conducted to confirm the identity of the most productive isolate of $X$. campestris. Fig. (2) explains the results of PCR amplification. The bacteria isolate showed a bright band at $1500 \mathrm{bp}$. Then the results showed the sequence of nitrogenous bases in the blast program of the National Center for Biotechnology Information (NCBI), which matched the local isolate $100 \%$ with the $X$. campestris MAFF 106181X strain (Fig. 3). The isolate has been recorded in the Japanese GenBank as $X$. campestris XCB1 and encoded with the code MZ262533, https://www.ncbi.nlm.nih.gov/nuccore/MZ262 533. 


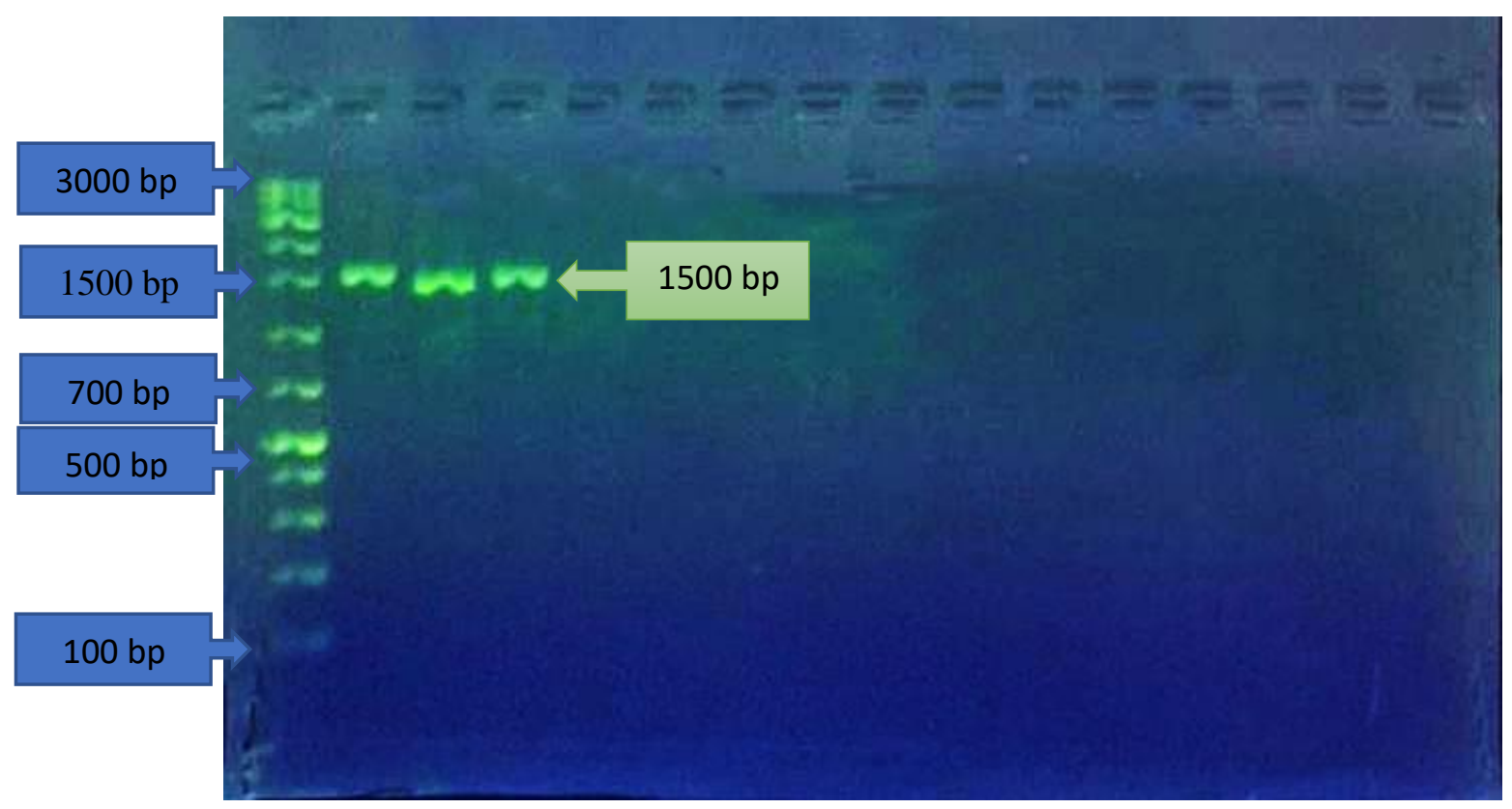

Fig. (2): Electrophoresis of the gene responsible for testing 16S rRNA for the X1 isolate on 1.5\% agarose gel.

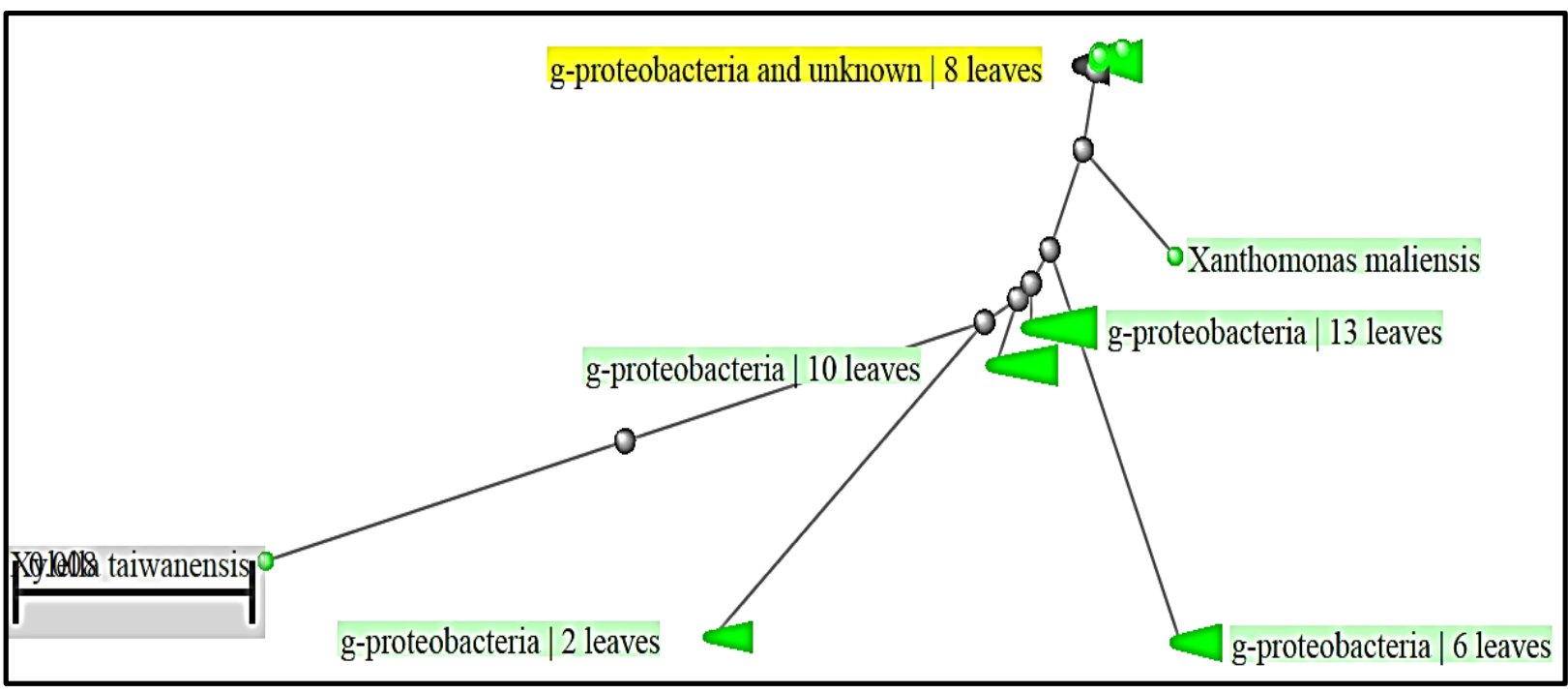

Fig. (3): The genetic tree of $X$. campestris XCB1 bacteria.

\section{Production of xanthan gum from date juice}

Fig. (4) shows the effect of using different concentrations of sugar in the form of date juice on xanthan gum production using $X$. campestris XCB1. The highest gum yield when using a concentration of $3.5 \mathrm{ml}$ of date juice $\left(1.5 \mathrm{~g}\right.$ glucose $\left.100 . \mathrm{ml}^{-1}\right)$ of the production medium was $18.9 \mathrm{~g} . \mathrm{l}^{-1}$, and the

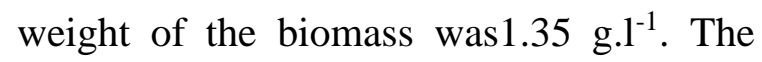


production of xanthan gum decreased as the concentration of date juice increased,

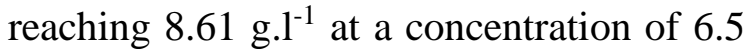
$\mathrm{ml}$ of date juice $\left(2.8 \mathrm{~g}\right.$ glucose $\left.100 \mathrm{ml}^{-1}\right)$ of the production medium. The statistical analysis showed significant difference between the standard medium and the date juice medium at a concentration of $3.5 \mathrm{ml}$ $\left(1.5 \mathrm{~g}\right.$ glucose $\left..100 \mathrm{ml}^{-1}\right)$ of medium. The is may be due to the presence of monosaccharides such as glucose and fructose and invert sugar. These substances stimulate bacteria to produce xanthan gum. The amount of biomass has decreased as gum production has increased, possibly due to the bacteria's proclivity to produce gum rather than biomass.

The findings corroborated those of Khosravi-Darani et al. (2011), who discovered that the best concentration of date juice as a carbon source in the production medium was $4 \mathrm{ml} / 100 \mathrm{ml}$ of the production medium and the resulting xanthan yield was $11.30 \mathrm{~g} . \mathrm{l}^{-1}$, while Salah et al. (2011), reported the best concentration of date juice when was used as a substitute for the carbon source in the production medium was at a concentration

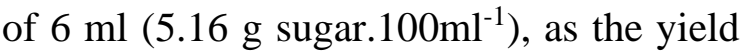
of the xanthan gum was 24.5 g. $\mathrm{l}^{-1}$.

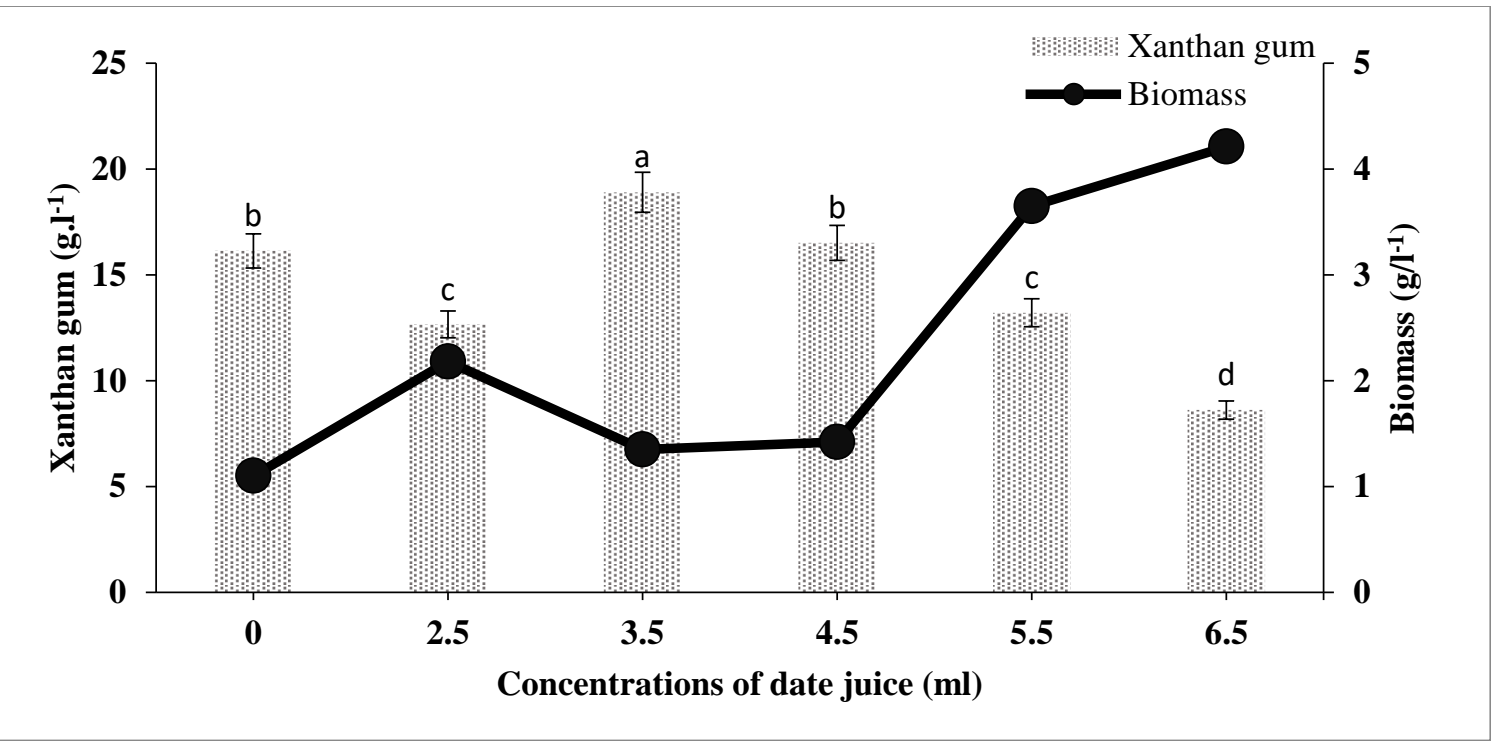

Fig. (4): Production of xanthan gum by isolate using different concentration of concentrations sugar in the form of date juice.

\section{Identification of Xanthan gum}

\section{FTIR spectrometer of xanthan gum}

Fig. (5) depicts the results of comparing xanthan gum produced from the standard medium and date juice XGP1 and XGP2 to the chemical xanthan gum XG using infrared spectroscopy technology that detects the vibrational frequencies of the functional groups present in the produced gum and XG. At the wavelength of $3406-3437 \mathrm{~cm}^{-1}$, a spectral absorption band appears, which is connected to hydroxyl group fluctuation, whereas the band at 2926-2933 $\mathrm{cm}^{-1}$ 


\section{Al-Roomi \& Al-Sahlany / Basrah J. Agric. Sci., 35(1): 35-49, 2022}

corresponds to $\mathrm{C}-\mathrm{H}$ and $\mathrm{CHO}$ groups. At 1732-1743 $\mathrm{cm}^{-1}$, a definite peak formed, which belongs to the acetate groups. While the $\mathrm{C}=\mathrm{O}$ groups of pyruvate appear at wavelengths of $1616-1622 \mathrm{~cm}^{-1}$, the $-\mathrm{COO}$ groups appear at wavelengths of 1409-1417 $\mathrm{cm}^{-1}$, and the $\mathrm{CO}$ group appears at wavelength $1234-1259 \mathrm{~cm}^{-1}$, and its peak at wavelength of $1051-1062 \mathrm{~cm}^{-1}$ is due to the C-O-C ether bond (Table 2). The slight differences in peaks that appear at close wavelengths may be due to changes in the chemical composition of the gum that result from the effects of different Xanthomonas strains, production conditions, type of growth medium and carbon source used. (Miranda $e t$ al., 2020). Infrared technology was used by Barua et al. (2016) to detect active groups of hydroxyls, carboxylic and carbonyl groups, as well as acetate groups, in xanthan gum.

Table (2): locations of the active groups of XG, XGP1 and XGP2 in the FTIR spectrometer.

\begin{tabular}{lccc}
\hline \multicolumn{1}{c}{ Effective group } & XG & XGP1 & XGP2 \\
\hline -OH & 3437 & 3414 & 3406 \\
C-H and CHO & 2926 & 2931 & 2933 \\
-C=O stretching of the acetate group & 1732 & 1734 & 1743 \\
C=O & 1616 & 1616 & 1622 \\
-COO groups & 1417 & 1409 & 1417 \\
CO of COC & 1253 & 1259 & 1234 \\
C-O-C stretching from ether linkages & 1051 & 1062 & 1053 \\
\hline
\end{tabular}

These results agree Rojas et al. (2019) when identifying the active groups in xanthan gum. A peak appeared for hydroxyl groups at wavelength $3410 \mathrm{~cm}^{-1}$, while wavelength $2935 \mathrm{~cm}^{-1}$ was due to $\mathrm{CH}_{2}$ and $\mathrm{CH}_{3}$ groups, and the peak that appeared at wavelength $1060 \mathrm{~cm}^{-1}$ was due to the $\mathrm{C}$-ether bond. The wavelength of the effective groups of xanthan gum when analyzed by infrared spectroscopy, was $3400-3450 \mathrm{~cm}^{-1}$, with a return to the hydroxyl groups, while the groups of $\mathrm{CH}$ and $\mathrm{CHO}$ peaks appeared at the wavelength of 2850-2950 $\mathrm{cm}^{-1}$, and the effective group $\mathrm{C}=\mathrm{O}$ appeared at the wavelength of $1700-1600 \mathrm{~cm}^{-1}$ (Pawlicka et al., 2019). 
Al-Roomi \& Al-Sahlany / Basrah J. Agric. Sci., 35(1): 35-49, 2022
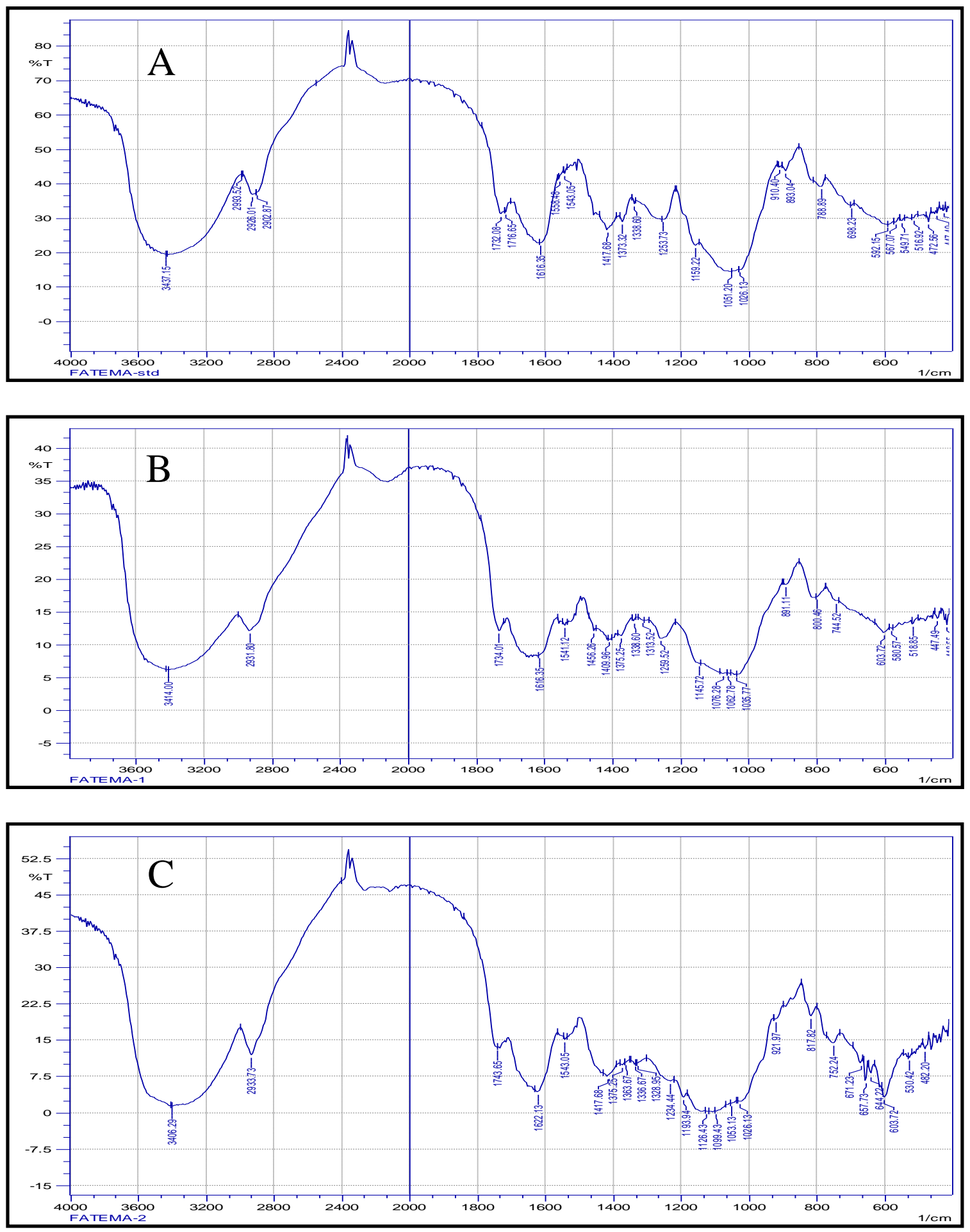

Fig. (5): FTIR analysis results for xanthan gum samples, where $A=G X, B=G X P 1$ and $C=G X P 2$.

Thin-layer chromatography (TLC) of xanthan gum
TLC technology was used to identify GXP1 and GXP2 compared to the chemical xanthan 
gum (GX) (Fig. 6). The relative movement $\mathrm{R} f$ of the stains of GXP1 and GXP2 was equal compared with the GX. It was equal to 0.6. The absence of other samples indicates the high purity of the Xanthan gum produced from the standard medium and the date juice. Gondim et al. (2019) mentioned that the reason for the differences in the intensity and size of spots when diagnosing xanthan gum using the thin layer chromatography technique is that the strains of the genus Xanthomonas produce polymers with different viscosities. The viscosity increases with increasing gum content of mannose sugar and glucuronic acid.

\section{High-performance liquid chromatography} of xanthan gum
XGP1 and XGP2 were identified and compared with chemical xanthan gum (XG) using HPLC technology. Fig. (7) shows the results of the identification. One clear, sharp peak appeared without any other peaks, indicating the purity of the produced gum. The retention time for the apparent peaks was 2.97, 2.94 and 3.03 minutes for XGP1, XGP2 and GX, respectively. A clear convergence in absorbance between the peaks was obtained at 290, 240 and $280 \mathrm{mAU}$, respectively. This confirms that the compound produced from the standard medium and the medium of date juice by the local isolate $X$. campestris XCB1 is xanthan gum.

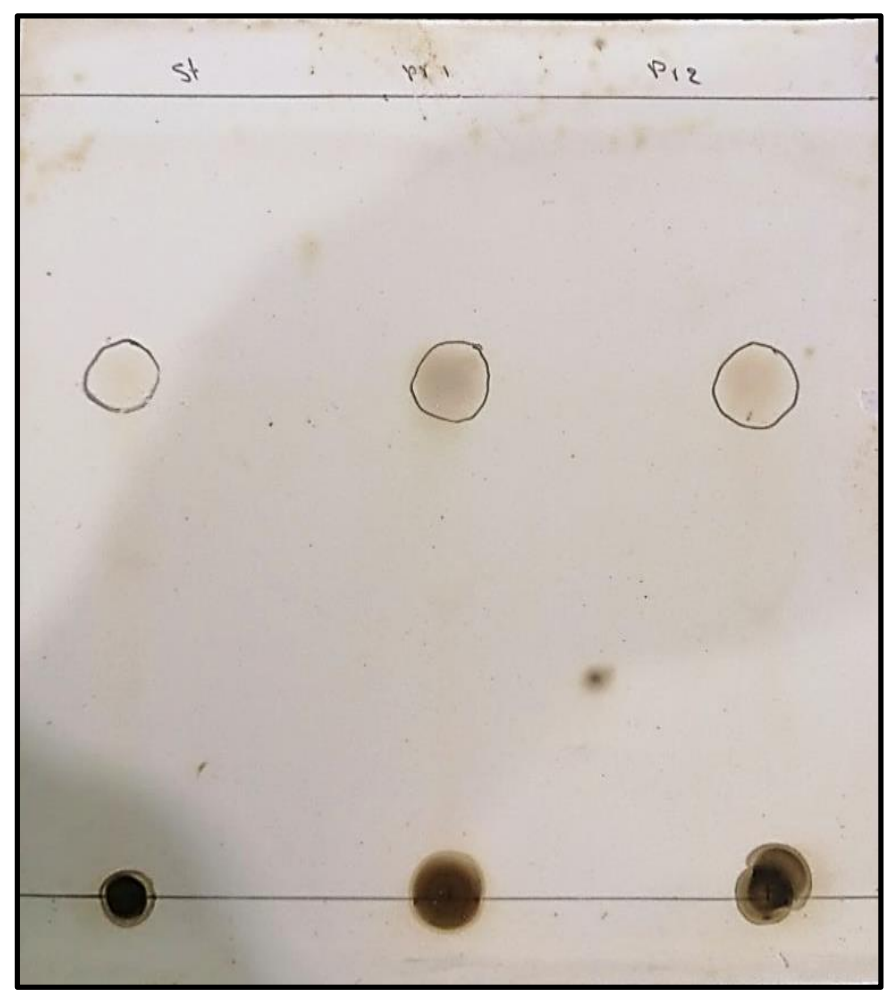

Fig. (6): Identify xanthan gum by using the thin layer chromatography technique of GX, GXP1 and GXP2 
Al-Roomi \& Al-Sahlany / Basrah J. Agric. Sci., 35(1): 35-49, 2022

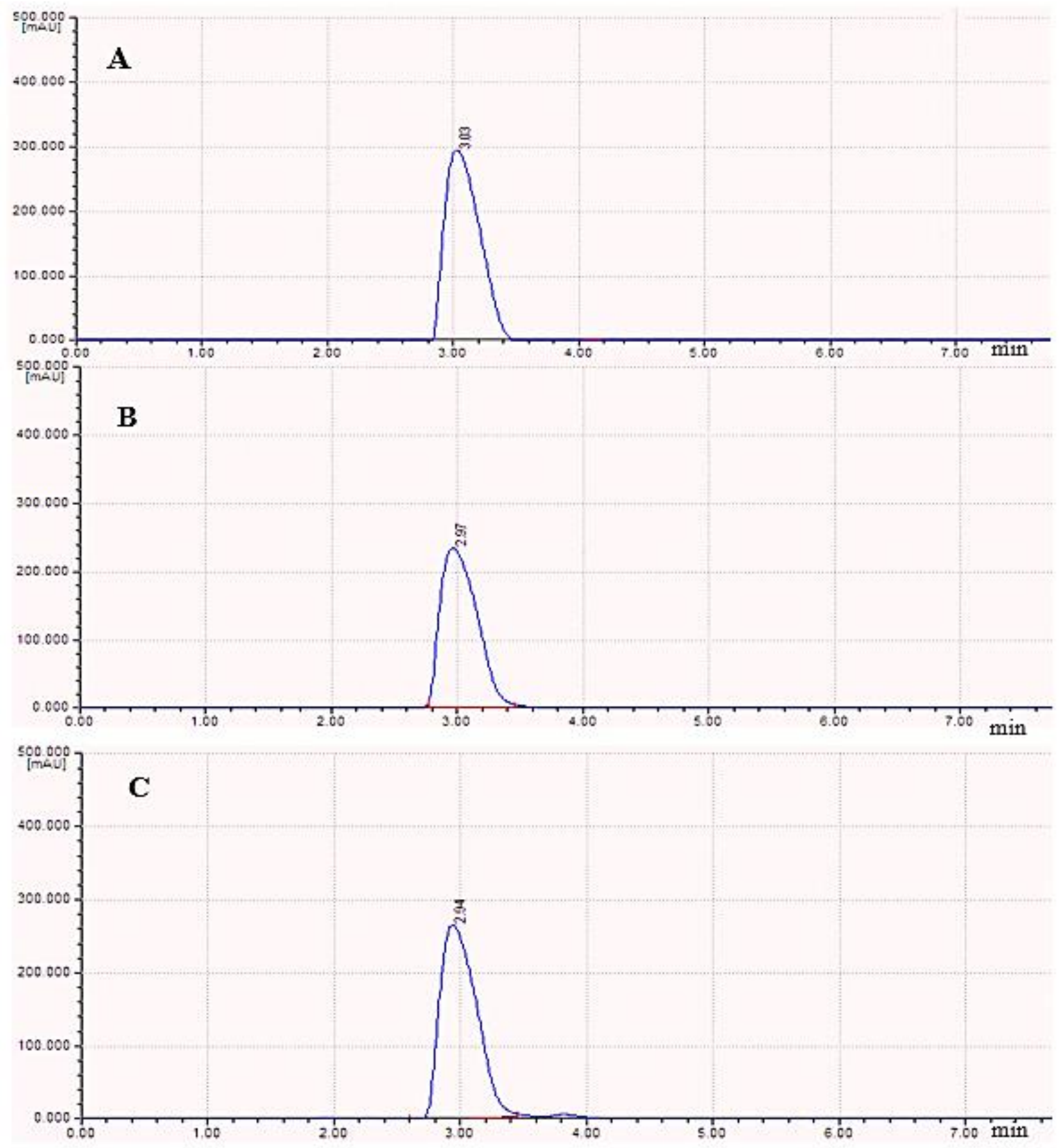

Fig. (7): HPLC analysis results for xanthan gum samples, where $A=X G, B=X G P 1, C=X G P 2$.

These results are in agreement with those reported by Salah et al. (2011), with a single, sharp peak at a holding time of 3.66 minutes for xanthan gum produced from a medium containing date juice. Papagianni et al. (2001) found that when xanthan gum was diagnosed using the HPLC technique, a single sharp peak appeared back to xanthan gum produced by $X$. campestris bacteria using a Luria-Bertani (LB) culture medium with $0.2 \%$ glucose addition. 


\section{Al-Roomi \& Al-Sahlany / Basrah J. Agric. Sci., 35(1): 35-49, 2022}

\section{Conclusions}

Microbial polysaccharides, including xanthan gum, are secondary metabolites produced by microorganisms which have nutritional and health benefits. It can be introduced into many food industries, and the product yield varies according to the type of strain and the agricultural media used. Agro wastes such as molasses and date extract (juice) have been used to reduce the economic cost of producing xanthan gum, as well as to get rid of agricultural waste that causes environmental damage.

\section{Acknowledgement}

The authors want to thank the department of food science and biotechnology, the College of Agriculture, the University of Basrah for financial support for this scientific work.

Conflicts of Interest: The authors declare no conflicts of interest.

\section{ORCID:}

S.T.G. Al-Sahlany. https://orcid.org/0000-0002-0617-6870

\section{References}

Abbaszadeh, A., Lad, M., Janin, M., Morris, G. A., MacNaughtan, W., Sworn, G., \& Foster, T. J. (2015). A novel approach to the determination of the pyruvate and acetate distribution in xanthan. Food Hydrocolloids, 44, 162-171. https://doi.org/10.1016/j.foodhyd.2014.08.014

Al-Gboori, B., \& Krepl, V. (2010). Importance of date palms as a source of nutrition. Agricultura Tropica et Subtropica, 43(4), 341-347.

Barua, R., Alam, M., Salim, M., and Ashrafee, T. S. (2016). Small scale production and characterization of xanthan gum synthesized by local isolates of Xanthomonas campestris. Indian Journal of Experimental Biology 54(2):151-155

da Silva, L. C. C., Targino, B. N., Furtado, M. M., de Oliveira Pinto, M. A., Rodarte, M. P., \& Hungaro, H.
M. (2017). Chapter 13. Xanthan: Biotechnological production and applications. 385-422. In Holban, A. M., \& Grumezescu, A. M. (Editors). Microbial Production of Food Ingredients and Additives. Academic Press. 518pp. https://doi.org/10.1016/B978-0-12-811520-6.00013-1

de Sousa Costa, L. A., Inomata Campos, M., Izabel Druzian, J., de Oliveira, A. M., \& de Oliveira Junior, E. N. (2014). Biosynthesis of xanthan gum from fermenting shrimp shell: Yield and apparent viscosity. International Journal of Polymer Science, 2014 Article ID 273650 https://doi.org/10.1155/2014/273650

Dubois, M., Gilles, K. A., Hamilton, J. K., Rebers, P. T., \& Smith, F. (1956). Colorimetric method for determination of sugars and related substances. Analytical chemistry, 28(3), 350-356. https://doi.org/10.1021/ac60111a017

Espert, M., Salvador, A., \& Sanz, T. (2019). Rheological and microstructural behaviour of xanthan gum and xanthan gum-Tween 80 emulsions during in vitro digestion. Food Hydrocolloids, 95, 454-461. https://doi.org/10.1016/j.foodhyd.2019.05.004

Gondim, T. S., Pereira, R. G., \& Fiaux, S. B. (2019). Xanthan gum production by Xanthomonas axonopodis pv. mangiferaeindicae from glycerin of biodiesel in different media and addition of glucose. Acta Scientiarum Biological Sciences, 41, e43661-e43661. https://doi.org/10.4025/actascibiolsci.v41i1.43661

Kalogiannis, S., Iakovidou, G., Liakopoulou-Kyriakides, M., Kyriakidis, D. A., \& Skaracis, G. N. (2003). Optimization of xanthan gum production by Xanthomonas campestris grown in molasses. Process Biochemistry, 39(2), 249-256. https://doi.org/10.1016/S0032-9592(03)00067-0

Khassaf, W. H., Niamah, A. K., \& Al-Manhel, A. J. (2019). Study of the optimal conditions of levan production from a local isolate of Bacillus subtilis subsp. subtilis w36. Basrah Journal of Agricultural Sciences, 32(2), 213-222. https://doi.org/10.37077/25200860.2019.211

Khosravi-Darani, K., Reyhani, F. S., Nejad, B. N., \& Farhadi, G. B. N. (2011). Bench scale production of xanthan from date extract by Xanthomonas 


\section{Al-Roomi \& Al-Sahlany / Basrah J. Agric. Sci., 35(1): 35-49, 2022}

campestris in submerged fermentation using central composite design. African Journal of Biotechnology, $10(62)$,

13520-13527. https://doi.org/10.5897/AJB11.018

Kyrova, E. I., Dzhalilov, F. S., \& Ignatov, A. N. (2020). The role of epiphytic populations in pathogenesis of the genus Xanthomonas bacteria. BIO Web of Conferences, 23(1), 03010. https://doi.org/10.1051/bioconf/20202303010

Loy, A., Lehner, A., Lee, N., Adamczyk, J., Meier, H., Ernst, J., Schleifer, K., \& Wagner, M. (2002). Oligonucleotide microarray for $16 \mathrm{~S}$ rRNA gene-based detection of all recognized lineages of sulfate-reducing prokaryotes in the environment. Applied and Environmental Microbiology, 68, 5064-5081. https://doi.org/10.1128/AEM.68.10.5064-5081.2002

Makut, M. D., Agbonkhese, P. E., \& Bello, A. (2018). Production of xanthan gum using Xanthomonas campestris isolated from some plants leaves in Keffi, Nigeria. Asian Journal of Biotechnology and Bioresource Technology, 3(4), 1-9. https://doi.org/10.9734/AJB2T/2018/42025

Miranda, A. L., Costa, S. S., Assis, D. D. J., de Jesus, C. S., Guimarães, A. G., \& Druzian, J. I. (2020). Influence of strain and fermentation time on the production, composition, and properties of xanthan gum. Journal of Applied Polymer Science, 137(15), 48557. https://doi.org/10.1002/app.48557

Mudoi, P., Bharali, P., \& Konwar, B. K. (2013). Study on the effect of $\mathrm{pH}$, temperature and aeration on the cellular growth and xanthan production by Xanthomonas campestris using waste residual molasses. Journal of Bioprocessing and Biotechniques, 3(2), 135. https://doi.org/10.4172/2155-9821.1000135

Ndongo, S., Beye, M., Dubourg, G., Nguyen, T. T., Couderc, C., Fabrizio, D. P., \& Angelakis, E. (2018). Genome analysis and description of Xanthomonas massiliensis sp. nov., a new species isolated from human faces. New Microbes and New Infections, 26, 63-72. https://doi.org/10.1016/j.nmni.2018.06.005

Nejadmansouri, M., Shad, E., Razmjooei, M., Safdarianghomsheh, R., Delvigne, F., \& Khalesi, M.
(2020). Production of xanthan gum using immobilized Xanthomonas campestris cells: Effects of support type. Biochemical Engineering Journal, 157, 107554. https://doi.org/10.1016/j.bej.2020.107554

Ocimati, W., Were, E., Groot, J. C., Tittonell, P., Nakato, G. V., \& Blomme, G. (2018). Risks posed by intercrops and weeds as alternative hosts to Xanthomonas campestris pv. musacearum in banana fields. Frontiers in Plant Science, 9, 1471. https://doi.org/10.3389/fpls.2018.01471

Palaniraj, A., \& Jayaraman, V. (2011). Production, recovery and applications of xanthan gum by Xanthomonas campestris. Journal of Food Engineering, 106(1), 1-12. https://doi.org/10.1016/j.jfoodeng.2011.03.035

Papagianni, M., Psomas, S. K., Batsilas, L., Paras, S. V., Kyriakidis, D. A., \& Liakopoulou-Kyriakides, M. (2001). Xanthan production by Xanthomonas campestris in batch cultures. Process Biochemistry, 37(1), 73-80. https://doi.org/10.1016/S00329592(01)00174-1

Pawlicka, A., Tavares, F. C., Dörr, D. S., Cholant, C. M., Ely, F., Santos, M. J. L., \& Avellaneda, C. O. (2019). Dielectric behavior and FTIR studies of xanthan gumbased solid polymer electrolytes. Electrochimica Acta, 305, 232-239. https://doi.org/10.1016/j.electacta.2019.03.055

Popović, T., Jošić, D., Starović, M., Milovanović, P., Dolovac, N., Poštić, D., \& Stanković, S. (2013). Phenotypic and genotypic characterization of Xanthomonas campestris strains isolated from cabbage, kale and broccoli. Archives of Biological Sciences, 65(2), 585-593. https://doi.org/10.2298/ABS1302585P

Prabhakar, A., Janaun, J., Woh, F. C., \& Bono, A. (2004). Studies on xanthan production from Xanthomonas campetris using tapioca starch as carbon source. In Asian Pacific Confederation of Chemical Engineering congress program and abstracts Asian Pacific Confederation of Chemical Engineers congress program and abstracts. 375-375. The Society of Chemical Engineers, Japan. https://doi.org/10.11491/apcche.2004.0.375.0 


\section{Al-Roomi \& Al-Sahlany / Basrah J. Agric. Sci., 35(1): 35-49, 2022}

Rojas, M., Peña, M., \& Peña-Vera, M. J. (2019). Characterization and determination of antimicrobial and metal resistant profiles of Xanthomonas strains isolated from natural environments. Journal of Analytical \& Pharmaceutical Research, 8(2), 55-60. https://doi.org/10.15406/japlr.2019.08.00312

Rottava, I., Batesini, G., Silva, M. F., Lerin, L., de Oliveira, D., Padilha, F. F., \& Treichel, H. (2009). Xanthan gum production and rheological behavior using different strains of Xanthomonas sp. Carbohydrate Polymers, 77(1), 65-71. https://doi.org/10.1016/j.carbpol.2008.12.001

Saddler, G. S., \& Bradbury, J. F. (2005). Xanthomonadalesord. nov. 63-122. In Garrity, G., Brenner, D. J., Krieg, N. R., \& Staley, J. R. (Editors). Bergey's manual of systematic Bacteriology. Vol. 2. Springer, Boston, MA. 1106pp. https://doi.org/10.1007/0-387-28022-7_3

Salah, R. B., Chaari, K., Besbes, S., Blecker, C., \& Attia, H. (2011). Production of xanthan gum from Xanthomonas campestris NRRL B1459 by fermentation of date juice palm by products (Phoenix dactylifera L.). Journal of Food Process Engineering, 34(2), 457-474. https://doi.org/10.1111/j.17454530.2009.00369.x
Soleymanpour, Z., Nikzad, M., Talebnia, F., \& Niknezhad, V. (2018). Xanthan gum production from acid hydrolyzed broomcorn stem as a sole carbon source by Xanthomonas campestris. 3 Biotech, 8(7), 1-12. https://doi.org/10.1007/s13205-018-1322-z

Sworn, G. (2021). Chapter 27. Xanthan gum. 833-853. In Phillips, G. O., \& Williams, P. A. (Editors). Handbook of hydrocolloids. $3^{\text {rd }}$ edition, Woodhead Series in Food Science, Technology and Nutrition Publishing., 1190pp. https://doi.org/10.1016/B978-012-820104-6.00004-8

Tilahun, B., Yinur, D., Zenabu, D., \& Menesha, F. M. (2020) Isolation and identification of Enset wilt disease causing bacteria using $16 \mathrm{~S}$ rRNA Gene Sequence samples collected from Gurage zone, Ethiopia. Journal of Life Science and Biomedicine, 10(4), 51-58. https://dx.doi.org/10.36380/scil.2020.jlsb7

Yuen, G. Y., Alvarez, A. M., Benedict, A. A., \& Trotter, K. J. (1987). Use of monoclonal antibodies to monitor the dissemination of Xanthomonas campestris pv. campestris. Phytopathology, 77(2), 366-370. https://doi.org/10.1094/Phyto-77-366

\section{Xanthomonas تثخيص وتوصيف صمغ الزانثان الناتج من عصير التمر باستعمال عزلة محلية لبكتريا \\ campestris}

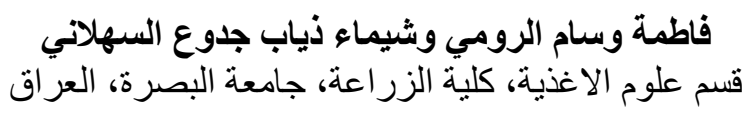

المستخلص: يعد صمغ الزانثان من السكريات المتعددة المايكروبية التي تتتج من البكتريا Xanthomonas spp استعملت سبع عزلات محلية عائدة لبكتريا Xanthomonas campestris بعد تثخيصها باختبارات المجهرية والكيموحيوية، غربلت العزلات على

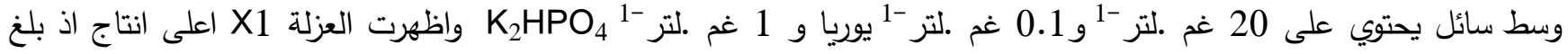
6.26 غم. لتر -1 تم تأكيد العزلة باختبار 16S rRNA وسجلت في بنك الجينات بالرمز MZ262533 عصير التمر بتركيز 3.5 مل (1.5 غم كلوكوز) / 100 مل من وسط الانتاج اذ بلغ اعلى حاصل 18.9 غم. لتر -1 شخص صمغ بـ الزانثان الناتج باستعمال تقنيات FTIR و واظهر تطابقاً مع صمغ الزانثان الكيميائي. يمكن استعمال اوساط بديلة من المخلفات الزراعية في انتاج صمغ الزانثان واستعماله في الاغذية. الكلمات المفتاحية: صمغ الزانثان، بكتريا Xanthomonas campestris، مستخلص التمر. 